\title{
Toxicity screening of biochar-mineral composites using germination tests
}

\author{
Jan Mumme \\ University of Edinburgh, UK Biochar Research Centre, Edinburgh, United Kingdom \\ Josephine Getz \\ Technological University Dublin \\ Munoo Prasad \\ Compost/AD Research \& Advisory (IE, Naas, Ireland
}

See next page for additional authors

Follow this and additional works at: https://arrow.tudublin.ie/beschrecart

Part of the Bioresource and Agricultural Engineering Commons, and the Geological Engineering Commons

\section{Recommended Citation}

Mumme, J., Getz, J. \& Prasad, M. (2018). Toxicity screening of biochar-mineral composites using germination tests. Chemosphere, vol. 27, Setember, pg. 91-100. doi:10.1016/j.chemosphere.2018.05.042

This Article is brought to you for free and open access by the School of Surveying and Construction Management at ARROW@TU Dublin. It has been accepted for inclusion in Articles by an authorized administrator of ARROW@TU Dublin. For more information, please contact arrow.admin@tudublin.ie, aisling.coyne@tudublin.ie, gerard.connolly@tudublin.ie.

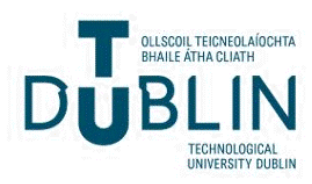




\section{Authors}

Jan Mumme, Josephine Getz, Munoo Prasad, Ulf Lüder, Kern Jurgen, Ondrej Masek, and Wolfram Buss

This article is available at ARROW@TU Dublin: https://arrow.tudublin.ie/beschrecart/59 


\section{Toxicity screening of biochar-mineral composites using germination tests}

2 Jan Mumme ${ }^{\mathrm{a}}$, Josephine Getz ${ }^{\mathrm{b}}$, Munoo Prasad ${ }^{\mathrm{c}}$, Ulf Lüder ${ }^{\mathrm{d}}$, Jürgen Kern ${ }^{\mathrm{e}}$, Ondřej

3 Mašek $^{\mathrm{a}}$, Wolfram Buss ${ }^{\mathrm{a}} *$

4

$5{ }^{a}$ UK Biochar Research Centre, School of GeoSciences, University of Edinburgh, Crew

6 Building, King's Building, Edinburgh EH9 3JN, U.K.

$7 \quad{ }^{\mathrm{b}}$ Environmental Sustainability and Health Institute, Dublin Institute of Technology,

8 Greenway Hub, Grangegorman, Dublin 1, D07 H6K8, Ireland

$9 \quad{ }^{\mathrm{c}}$ Compost Research \& Advisory, Naas, Ireland

$10{ }^{\mathrm{d}}$ SunCoal Industries GmbH, Rudolf-Diesel-Straße 15, 14974 Ludwigsfelde, Germany

$11{ }^{\mathrm{e}}$ Leibniz Institute for Agricultural Engineering Potsdam-Bornim, Max-Eyth-Allee 100,

1214469 Potsdam, Germany

$13 *$ Corresponding author. email: w.buss@ed.ac.uk 


\section{Abstract}

15 This study assessed the properties and toxicity (water cress germination trials) of 38

16 waste-derived, novel biochar-mineral composites (BMCs) produced via slow pyrolysis

17 and hydrothermal carbonization (hydrochars). The biochars were produced from sewage

18 sludge and compost-like output (CLO) by varying the type of mineral additive (zeolite,

19 wood ash and lignite fly ash), the mineral-to-feedstock ratio and the carbonization

20 process. While pure hydrochars completely inhibited germination of water cress, this

21 effect was ameliorated by mineral additives. Seedlings grew best in pyrolysis chars and

22 while wood ash addition decreased plant growth in many cases, 1:10 addition to CLO

23 doubled germination rate. The factors responsible for the phytotoxicity can be attributed

24 to $\mathrm{pH}$, salinity and organic contaminants. Importantly, while pure minerals inhibited

25 germination, conversion of minerals into BMCs reduced their inhibitory effects due to

26 buffered release of minerals. Overall, mineral wastes (e.g., combustion ashes) and waste

27 biomass can be used safely as sources of nutrients and stable organic carbon (for soil

28 carbon sequestration) when converted into specific biochar-mineral composites,

29 exploiting synergies between the constituents to deliver superior performance.

30 Keywords: Biochar; Hydrochar; Pyrolysis; HTC; Ash; BMC

31 Abbreviations ${ }^{1}$

\footnotetext{
${ }^{1}$ EC, electric conductivity; BMC, biochar mineral composites; CLO, compost-like output; HTC, hydrothermal carbonization
} 
33 Biochar is the solid, carbon-rich fraction obtained from thermochemical conversion of

34 biomass in an oxygen-limited environment (International Biochar Initiative, 2011).

35 Biochars can be differentiated into chars from pyrolysis, which is a process that takes

36 place at temperature of $350-750^{\circ} \mathrm{C}$, and hydrochars formed at temperatures of 180 -

$37250^{\circ} \mathrm{C}$ at elevated pressures in subcritical, liquid water (Lehmann and Joseph, 2015;

38 Libra et al., 2011). During the last decade, a growing interest in the use of biochar

39 surfaced, ranging from soil amendment for higher crop productivity (Lehmann and

40 Joseph, 2015; Liu et al., 2013), carbon sequestration (Wang et al., 2015) and

41 environmental remediation (Xie et al., 2015) to the support of chemical (Zhu et al.,

42 2015) and biological (Mumme et al., 2014) processes.

43 Biochar represents a highly heterogenic group of materials and its properties depend on

44 the nature of feedstock and production conditions. When applied to soil its value derives

45 mainly from its chemical stability, high surface area, cation exchange capacity, high $\mathrm{pH}$,

46 nutrient provision ( $\mathrm{P}, \mathrm{K}, \mathrm{Ca}, \mathrm{Mg}$ ) and sorption capacity. However, biochar has also been

47 reported to exhibit adverse effects on plant growth, water and soil organisms in a

48 number of studies caused by sorption of $\mathrm{N}$, organic/inorganic contaminants and high $\mathrm{pH}$

49 and salinity levels (Bargmann et al., 2013; Busch et al., 2013; Buss et al., 2016b; Buss

50 and Mašek, 2014; Gell et al., 2011; Kołtowski and Oleszczuk, 2015; Lucchini et al.,

51 2014; Oleszczuk et al., 2013; Prommer et al., 2014; Smith et al., 2013).

52 A way to influence the physical and chemical properties of biochar, such as stability or

53 carbon retention, is the addition of minerals prior to the production of pyrolysis chars

54 (Li et al., 2014; Xu et al., 2017) or hydrochars (Mumme et al., 2015). The addition of

55 minerals to biochar before or after thermal treatment creates a new product called 
56 biochar mineral composites (BMC). Apart from the potential of influencing the physical

57 and chemical properties, minerals add plant nutrients to the resulting product.

58 Overall, BMC's have been studied in only a few articles which in most cases used

59 existing biochars to produce BMCs (Blackwell et al., 2015; Chia et al., 2014; Lin et al.,

60 2013). In our study, as previously conducted by Mumme et al. (2015) the feedstocks

61 and minerals were mixed before thermal treatment. This study is the first to screen

62 waste-derived BMCs produced by both HTC and pyrolysis for potentially phytotoxic

63 effects and general properties. Seed germination and early seedling growth are very

64 sensitive to the influence of external factors and therefore, germination trials in a

65 controlled, soil-free environment were conducted to assess BMC's toxicity.

66 Overall, 38 different biochars were produced from two different feedstocks with

67 different production technologies / conditions and three different minerals added in

68 different ratios. The objective was to investigate the effects of BMCs on seed

69 germination and early seedling growth of watercress as model organism as the first step

70 towards evaluating the safety of BMCs. Properties, such as $\mathrm{pH}$, electric conductivity

71 (EC), ash content and elemental content ( $\mathrm{CHN}$, nutrient and potentially toxic elements)

72 were assessed. Furthermore, the aim was to investigate whether potential inhibitory

73 effects of pure minerals are reduced by incorporation into BMCs. 


\section{Materials and methods}

75

76

77

78

\subsection{Origin and properties of organic feedstocks and minerals}

To demonstrate economic feasibility, we decided that the minerals and the feedstocks for thermochemical conversion should both be waste materials (marginal biomass). Therefore, in this study, compost-like output (CLO), a byproduct from composting made of partially degraded residues that is often landfilled (Donovan et al., 2010) and sewage sludge were used as feedstocks.

The sewage sludge was obtained from Daldowie wastewater treatment site (Glasgow, Scotland), where it was first mechanically dewatered using a centrifuge, then dried and pelletized. The CLO was obtained as a waste product from a compost facility in Ireland from the mechanical separation of mixed municipal solid waste (fraction $<20 \mathrm{~mm}$ ).

The organic feedstocks were mixed with three different minerals: wood ash, fly ash and, for reference, zeolite. The wood ash was retrieved from a manually-fed $50 \mathrm{~kW} \log$ wood boiler with flue gas venting (Atmos, Czech Republic), which was fed with a 70:30 mixture of dry oak and robinia wood. The fly ash was obtained from AHG Industry GmbH \& Co. KG and derived from lignite coal burning in HKW Chemnitz, Germany. A natural hydrated zeolite with particle size 0-100 $\mu \mathrm{m}$ mainly composed of clinoptilolite (90-92\%), cristobalite (5-7\%), feldspar (2-4\%), mica (1-2\%), and quartz (traces) was obtained from Zeolithversand LTD (Germany). Further information about the zeolite can be obtained from Mumme et al. (2015).

\subsection{Production of BMCs}

CLO and sewage sludge were mixed with a definite amount of minerals prior to thermochemical conversion in ratios of 10:1 (100 g source material and $10 \mathrm{~g}$ mineral) and 1:1 
97 (50 g and $50 \mathrm{~g})$. The ratios are based on dry matter (TS $\left.105^{\circ} \mathrm{C}\right)$. Overall, 28 different

98 hydrochars were produced and 10 different pyrolysis chars. An overview of all samples

99 is shown in Table 1 and SI Table 1.

$100 \quad 2.2 .1 \quad H T C$

101 All HTC experiments were performed in a one-liter stir reactor (Parr Instruments,

102 Moline, IL, USA, model 4520) with the respective mixtures and addition of distilled

103 water to a volume of $700 \mathrm{~mL}$. The reactor was heated with a performance of $2^{\circ} \mathrm{C} \mathrm{min}$

104 to the initialized holding temperature of $190^{\circ} \mathrm{C}$ or $230^{\circ} \mathrm{C}$ regulated by the software

105 SpecView. Over the whole timespan the stirrer was turning with $90 \mathrm{rpm}$ and at the end

106 of the holding time (120 minutes) the heaters were switched off. The samples were left

107 to cool to room temperatures for 3 hours. The HTC product (slurry) was filtered through

108 a 5-8 $\mu$ m paper filter via -0.200 mbar vacuum filtration; the solids were dried at $105^{\circ} \mathrm{C}$

109 for 24 hours.

$110 \quad$ 2.2.2 Pyrolysis

111 Prior to pyrolysis the feedstocks were homogenized. A swing mill of type RS 200 from

112 Retsch and a grinding application made of $98 \%$ pure iron was used for grinding the

113 materials at $1400 \mathrm{rpm}$ for 90 seconds. The mixture ratios were identical to the HTC

114 experiments, however, lignite fly ash was not tested. An overview of all the treatments

115 and produced biochars is shown in Table 1. The mixtures were filled in a fireclay

116 crucible made of ceramic with a capacity of $30 \mathrm{~g}$. The holding time at highest treatment

117 temperature (HTT) for CLO was set to 20 minutes. Because of a different reaction

118 behavior of sewage sludge in pyrolysis (initial endothermic reaction) the holding time at

119 HTT was 25 minutes to guarantee complete carbonization. The crucibles were inserted

120 and removed at the $\mathrm{HTT}$ of $550^{\circ} \mathrm{C}$ to prevent a temperature drift. The atmosphere in the 
121 furnace was kept inert through a nitrogen flow of $12 \mathrm{~L} \mathrm{~h}^{-1}$. The pyrolysis chars were left

122 to cool at room temperature closed with a lid to prevent ashing of the char.

\subsection{Germination tests}

124 All materials tested in this study are typically used as soil amendments and therefore,

125 instead of applying pure materials, a $1 \%$ application rate in sand was tested. This is a

126 comparably high concentration applied to a material with very low buffering capacity

127 compared to soil. The results, therefore, will indicate realistic, but still worst-case

128 scenario effects of the materials on germination and early seedling growth. An adapted

129 version of the EN 16086-2 2011 method was used with sand as control instead of peat

130 allowing for direct comparisons.

131 Hydrochars and pyrolysis chars were stored in closed containers for around two months

132 at room temperature between production and testing in the germination assays. All

133 additives were mixed with sand at a $1 \%$ rate (dry base) and the sand was wetted before

134 with DI water to reach $80 \%$ of its water holding capacity (WHC). The medium sand

135 used for the germination test contained particles of $50-70$ mesh $(210-297 \mu \mathrm{m})$ (Sigma-

136 Aldrich Company Ltd., UK). The petri dishes used for the trial contained a filter paper

137 and an amount $0.9 \mathrm{~g}$ de-ionized water which is equivalent to $80 \%$ of theWHC of the

138 filter paper. The WHC of the sand was determined by soaking $5 \mathrm{~g}$ of sand in water for 1

$139 \mathrm{~h}$ which was first drained for $18 \mathrm{~h}$ and subsequently dried in an oven at $80^{\circ} \mathrm{C}$.

140 The BMC's were weighed into plastic bags, mixed with sand, water was added and they

141 were mixed again. Each petri dish was filled with $36.6 \mathrm{~g} \pm 0.1 \mathrm{~g}$ of the wet mix and 10

142 seeds of Nasturtium officinale (watercress) were spread. The experiment was replicated

143 four times per treatment. As per method, the petri dishes were sealed with parafilm. The 
144 dishes were stored in a temperature control room at around $25^{\circ} \mathrm{C}$ in an angle of 50

145 degrees for seven days to germinate. A schematic of the test can be found in SI Figure 1462.

147 The treatments were assessed in two germination batches (SI Table 1). Seeds were

148 considered to have germinated if the radicle had emerged. Root and shoot length were

149 determined by image analysis using software ImageJ version 1.50i.

\section{$150 \quad 2.4 \quad$ Analysis of biochar properties}

\section{$151 \quad 2.4 .1 \quad$ Electric conductivity (EC) and $p H$}

152 For EC and $\mathrm{pH}$ measurements $1 \mathrm{~g}$ of biochar was mixed with distilled water in a ratio of

$153 \quad 1: 20$ and the mixture was shaken for $1.5 \mathrm{~h}(12 \mathrm{~h}$ and $54 \mathrm{~h})$ on a bench-top shaker

154 according to Rajkovich et al. (2012) which is the method recommended by the

155 International Biochar Initiative (IBI, 2014) for analysing biochar. The EC and pH were

156 measured using a HM digital EC probe (model COM-100) and a Mettler Toledo FE 30,

157 respectively.

$158 \quad 2.4 .2 \quad$ Elemental content via ultimate analysis

159 The CHNS elemental content was determined using a Vario EL III elemental analyzer

160 (Elementar Analysensysteme GmbH, Germany).

$161 \quad 2.4 .3 \quad$ Elemental content via ICP-OES

162 The feedstocks and biochars were digested using modified dry ashing which is a method 163 that has been optimized for biochar (Enders and Lehmann, 2012). The digested samples

164 were analyzed using an iCAP 6000 Series Inductively Coupled Plasma - Optical

165 Emission Spectrometry (ICP-OES) (Thermo Fisher Scientific, Waltham, MA, USA).

166 Overall 23 elements were analyzed and nutrient concentrations are reported in Table 2, 


\section{$167 \quad 2.5 \quad$ Statistics}

168 Germination test results were analyzed using one-way ANOVA, followed by Tukey

169 post hoc tests with a significance level of 0.05 was applied. 


\section{Results and discussion}

\subsection{Material properties of Biochar and BMCs}

172 Compared to pyrolysis, during HTC less dehydration and aromatization reactions take

173 place and hence more carbon is conserved in relation to the mineral content which

174 results in higher carbon and hydrogen contents in hydrochars (Table 1 and Table 2)

175 (Libra et al., 2011). Additionally, while minerals dissolve into the HTC liquor to some

176 degree (Libra et al., 2011), during pyrolysis most minerals are retained in the pyrolysis

177 char (Buss et al., 2016a). This results in lower ash contents of hydrochars compared to

178 pyrolysis chars which along with formation of organic acids also lowers the $\mathrm{pH}$ values

179 of hydrochars. This is particularly apparent for hydrochars from sewage sludge and less

180 so in the CLO-derived samples. Pyrolysis, increased the $\mathrm{pH}$ compared to the raw

181 materials (Table 1 and Table 2) as reported in other studies (Cantrell et al., 2012; Jindo

182 et al., 2014; Ronsse et al., 2013).

183 Thermo-chemical conversion and mineral addition had a stronger influence on $\mathrm{pH}$, ash

184 and elemental composition of biochar from sewage sludge than it had on CLO-

185 biochars. This can be attributed to the already high ash content in the untreated CLO of

$18655.0 \%\left(a_{550}\right.$, Table 2 ) compared to $29.7 \%$ in raw sewage sludge. Consequently, e.g.

187 the content of $\operatorname{ash}_{550}$ of hydrochars produced at $190^{\circ} \mathrm{C}$ changed with $1: 1$ wood ash

188 addition from: $39.4 \%$ to $71.7 \%$ for sewage sludge but only from $66.6 \%$ to $84.3 \%$ for

189 CLO (Table 1 and Table 2). Addition of minerals decreased the $\mathrm{C}, \mathrm{N}, \mathrm{H}$ and $\mathrm{S}$ contents

190 of the biochars as expected because the ash fraction is mostly inert and hence increases

191 proportionally (Table 1 and Table 2). The 1:1 mineral additions resulted in biochars

192 with ash contents in the range of $70-90 \%$. 
193 Wood ash addition to the biomass feedstocks in the ratio of 1:1 resulted in EC values in

194 the pyrolysis BMCs of only $1 / 4$ (sewage sludge) and 1/3 of the EC of pure wood ash

195 (Table 1 and Table 2). The ECs are expected to be $>1 / 2$ of the wood ash EC value due

196 to enrichment of the ash fraction during pyrolysis and addition of ash from the biomass

197 feedstocks. This clearly shows that addition of biomass and conversion into biochar

198 buffers the release of minerals and reduces the EC. With the addition of wood ash and

199 lignite fly ash, the BMCs contained exceptionally high concentrations of the

200 macronutrients, $\mathrm{P}, \mathrm{K}, \mathrm{Ca}, \mathrm{Mg}, \mathrm{S}$ and $\mathrm{N}$ which could make them an ideal compound

201 fertilizer (Table 1, Table 2, Table 3, Table 4). However, it is important that they do not

202 exhibit any phytotoxic effects which is investigated in the following sections.

2033.2 Germination and seedling growth in feedstock materials and minerals

204 Compared to the sand-only controls, watercress seed germination was significantly

205 inhibited by all unpyrolysed feedstock amendments (Fig. 1). The inhibition ranged from

206 around 50\% (sewage sludge, zeolite) to $100 \%$ (wood ash).

207 The complete inhibition of germination caused by wood ash can clearly be attributed to

208 its high $\mathrm{pH}(12.78$, Table 1) and osmotic potential/salinity, here approximated by

209 measuring the EC $\left(16,100 \mu \mathrm{S} \mathrm{cm}^{-1}\right.$, Table 1) which were the most relevant factors in

210 other studies, such as Etiegni et al. (1991). More specifically Etiegni et al. (1991) and

211 Buss et al. (2016b) attributed the toxic effects mostly to the exceptionally high

212 potassium (K) concentration in wood ash / biochars, which we do see in our wood ash

213 as well: more than $7.5 \%$ of the wood ash sample is potassium (Table 3). Fly ash has a

214 very similar $\mathrm{pH}(12.54)$ to wood ash and zeolite has the second highest concentration of

$215 \mathrm{~K}$ of the materials (Table 3) which very likely were the reasons for the low germination 
216 rates in these treatments (Fig. 1). It is unlikely that heavy metals caused toxicity directly

217 although they will have contributed to the high osmotic potential (Buss et al., 2016b).

218 Salinity / K concentration and $\mathrm{pH}$, however, does not explain the low germination rate

219 caused by addition of CLO and sewage sludge. Ramírez et al. (2008) reported that fresh

220 sewage sludge applied to artificial soil in similar concentrations as in our study $(\sim 1 \%)$

221 reduced the germination rate in seeds of various plant species and the toxicity correlated

222 well with total $\mathrm{N}$ and $\mathrm{NH}_{4}{ }^{+}$contents. Fresh compost can also result in phytotoxic effects

223 due to the presence compounds such as $\mathrm{NH}_{4}{ }^{+}$(Wong, 1985). In our study, pure CLO (N

$2242.49 \%$, Table 2) and sewage sludge (N 4.28\%, Table 1) had the highest $\mathrm{N}$ contents of

225 the materials by far which indicates that indeed $\mathrm{NH}_{4}{ }^{+}$was responsible for the

226 germination inhibition caused by the two raw materials (Fig. 1).

227 After germination, the seedlings grown in sand amended with sewage sludge and CLO

228 showed significantly longer shoots and roots compared to the sand-only controls (Fig.

229 1). Similar to this result, in Ramírez et al. (2008), despite inhibition of germination,

230 sewage sludge did not affect shoot growth negatively and in some cases even stimulated

231 growth. After germination, the macronutrient $\mathrm{N}\left(\mathrm{NH}_{4}{ }^{+}\right)$(Monaco et al., 2003), $\mathrm{K}$ (Penny

232 et al., 1976) and P (Jaworski and Valli, 1964) demonstrate positive effects on shoot

233 growth in the early seedling development which explains the effects in our trial. While

234 sewage sludge and CLO both have high N contents (Table 1 and Table 2), additionally

235 sewage sludge has a high concentration of P (1.1\%, Table 3$)$ and CLO a high content of

$236 \mathrm{~K}(0.8 \%$, Table 4$)$.

237 Overall, application of the untreated amendments is problematic for various reasons

238 (e.g., osmotic potential, high $\mathrm{pH}, \mathrm{NH}_{4}{ }^{+}$). Yet, the amendments also resulted in positive 
239 effects on seedling growth after germination due to their high nutrient contents. This

240 shows the need for mixing different materials and using treatments, such as

241 thermochemical conversion, to mitigate the inhibitory effects and improve the growth

242 stimulating effects of the materials.

$243 \quad 3.3 \quad$ Germination and seedling growth in pure biochars

244 Pyrolysis mitigated the germination inhibition caused by pure sewage sludge

245 completely and increased the germination rate of seeds grown in CLO from 10 to $45 \%$.

246 Yet, HTC treatment increased the toxicity of both materials (Fig. 2).

247 During thermo-chemical conversion, nitrogen $(\mathrm{N})$ vaporizes or is washed into the HTC

248 liquor readily (Antal and Grønli, 2003; Libra et al., 2011), resulting in lower N

249 concentrations in biochar compared to its parent material (Table 1 and Table 2).

250 Furthermore, high-temperature treatment converts N-containing compounds into

251 heterocyclic (unavailable) N-structures (Yao et al., 2010). Consequently, the seeds

252 exposed to pyrolysed sewage sludge and CLO germinated mostly unhampered of the

253 influence of excess $\mathrm{N}$ (Fig. 2).

254 Pyrolysed compost still only showed a germination rate of $46 \%$ with a high standard

255 deviation indicating borderline toxicity. This can be explained by the elevated $\mathrm{pH}$ of

2568.95 (Table 2) which is the lower range where germination inhibition can occur (Henig-

257 Sever et al., 1996; Singh et al., 1975). Seed germination decreases exponentially with

$258 \mathrm{pH}$ as described in Buss et al. (2016b) and therefore, only some seeds reacted to the

259 high of pyrolysed compost. The shoot and root length of seedlings in the sewage sludge

260 treatment increased significantly after pyrolysis, however, no improvement was visible 
261 in the pyrolysed CLO treatment which already displayed very high shoot and root

262 length prior to pyrolysis (Fig. 1 and 2).

263 During HTC, mobile organic compounds that are formed during the process are not

264 separated from the char as effectively as during pyrolysis which can result in elevated

265 concentrations of potentially toxic organics, such as phenols and organic acids (organics

266 not measured in this study but reported in Bargmann et al. (2013)). Consequently, fresh

267 hydrochars can cause inhibitions on germination and during early seedling growth

268 (Bargmann et al., 2013; Busch et al., 2013). Our hydrochars were stored in closed

269 containers for around two months before testing in germination assays which does not

270 enable volatilization of organic compounds from the char. Therefore, inhibition by

271 organic compounds originated from the HTC process is the most probable cause for the

272 hydrochar effects in the germination tests. Different post-treatment measures were

273 successful in reducing the toxicity of fresh hydrochars (Bargmann et al., 2013; Busch et

274 al., 2013) and would also need to be implemented prior to application of our

275 hydrochars. 
277 The interactions of feedstock type, treatment method/temperature and mineral addition

278 were very complex; some of the key features are discussed in the following.

279 Zeolite addition increased germination rate compared to the non-amended treatments.

280 Zeolite has the ability to adsorb metals and organic compounds such as those present in

281 HTC char, which have the potential for inhibitory effects, and this could explain the

282 increased germination rate of zeolite-amended chars (Bargmann et al., 2013; Chao et al., 283 2012).

284 The highest germination rates for mineral-amended sewage sludge-derived hydrochars were in the range of $30-60 \%$ (for all 1:1 mineral additions and 1:10 fly ash addition treated at $190^{\circ} \mathrm{C}$ ) which is similar to untreated sewage sludge (Fig. 1) and higher than unamended sewage sludge-derived hydrochars (Fig. 3).

288 Ash addition also affected shoot and root growth. With 1:1 wood ash addition the shoots of seedlings grown in sewage sludge hydrochar increased from $12 \mathrm{~mm}$ for $190^{\circ} \mathrm{C}$ (no germination at $\left.230^{\circ} \mathrm{C}\right)$ to $35 / 36 \mathrm{~mm}\left(190^{\circ} / 230^{\circ} \mathrm{C}\right)($ and $18 / 16 \mathrm{~mm}$ for the $10: 1$

291 addition). This is higher than the length of the seedlings grown in the pure sewage 292 sludge treatment $(20 \mathrm{~mm})$ and similar to the shoot length of seedlings in sewage sludge 293 pyrolysed at $550^{\circ} \mathrm{C}(38 \mathrm{~mm}$ ) (Fig. 2) (highest shoot length of all sewage sludge 294 treatments. Therefore, when the seedlings germinated, they grew unhampered. The 295 organic contaminants only inhibited or delayed germination and did not completely 296 suppress plant growth as observed previously (Bargmann et al., 2013).

297 Overall, wood and fly ash addition increased the germination rate and growth of shoots and roots for sewage sludge and CLO significantly, while the shoot/root ratio was 
299 barely influenced by any of the minerals (Fig. 3, SI Table 5). The most probable reason

300 for the lower toxicity of hydrochars amended with minerals is the smaller organic

301 fraction in the feedstocks and subsequently fewer precursors for the formation of

302 potentially toxic organics, such as phenols and organic acids.

303 Not all of the phytotoxic effects, mitigation of toxic effects and beneficial effects can be

304 explained here. It is likely that a combination of various factors, mostly EC, $\mathrm{pH}$,

305 concentration of nutrients and, most important for hydrochars, the concentration of

306 organic contaminants has caused the effects. The highest germination rates were

307 observed in the range of $40-60 \%$ with many in the range of $0-20 \%$. This demonstrates

308 thathydrochar-BMCs still caused significantly phytotoxic effects and should be post-

309 treated before use as soil amendment.

310 The addition of $1 \% \mathrm{BCMs}$ to sand is a high application rate if applied mostly to supply

311 nutrients and tested as a worst-case scenario of effects on plant growth. Application in

312 lower rates some time before sowing of the seeds is likely to give enough time for

313 vaporization of the volatile organics which could be sufficient for post-treatment. The

314 results show that mineral addition does increase the germination rate and shoot and root

315 length compared to non-amended treatments. In addition, minerals incorporated into

316 hydrochars resulted in better plant performance than pure minerals. Hence, mixing

317 minerals with feedstock prior to thermo-chemical conversion brings advantages over

318 applying both products separately. 
320 Generally, the seeds performed best when grown in the pyrolysis chars (Fig. 4, SI Table

321 5). Zeolite addition to sewage sludge and CLO did not affect germination or seedling

322 growth (Fig. 4). Wood ash addition reduced the germination rate when mixed with

323 compost in both ratios and reduced the germination rate when blended with CLO in the

324 ratio 1:1, however, increased the germination rate when blended 1:10 compared to the control (SI Table 5).

Pyrolysis-derived BMCs amended with wood ash most likely caused toxic effects due to the high $\mathrm{pH}$ and the high osmotic potential (salinity) of the BMCs (Table 1 and Table 2). This is presented in SI Fig. 1 with a line of linear regression between germination rate and $\mathrm{pH}$ of the pyrolysis chars. SI Fig. 1 also demonstrates that the hydrochars with 1:1 mineral addition exhibited stronger toxic effects than pyrolysis chars with comparable $\mathrm{pHs}$ which is attributed to additional adverse effects from organic contaminants. The remaining 20 hydrochars are not shown in SI Fig. 1, their germination rates were even less well correlated with $\mathrm{pH}$ because their toxicity was nearly exclusively caused by organic contaminants. Under normal circumstance, the production of pyrolysis chars results in very low concentration of organic contaminants (Buss et al., 2015) and $\mathrm{pH}$ and osmotic pressure (salinity) are the factors that affect

337 plant growth adversely (Buss et al., 2016b) resulting in the linear correlation between 338 germination rate and $\mathrm{pH}$ (SI Fig. 1).

339 Despite some reduction of germination rate, the seedlings grown in pyrolysis chars 340 performed best. Typically, pyrolysis chars neither contain high concentrations of easily 341 available $\mathrm{N}$-containing compounds as the raw material do, nor do they contain mobile 342 organic contaminants as the hydrochars. Although some pyrolysis chars reduced 
343 germination rate, once germinated all pyrolysis char treatments increased the shoot and

344 root growth significantly by a factor of 2-5 compared to the sand only control, most

345 probably due to nutrient supply (SI Table 5). As described in 3.1, the wood-amended

346 BMCs showed lower ECs than would be expected considering the amount of wood

347 added (and the volatilization of organics).

348 This clearly demonstrates that pyrolysis-derived BMCs can increase plant growth and

349 are promising nutrient providers and liming agents.

\section{Conclusions}

351 Cress seeds grown in many pyrolysis-derived BMCs exhibited better growth

352 performance than the sand-only control and can be used safely. Raw materials (ash,

353 compost, sewage sludge), several pyrolysis chars and most hydrochars decreased

354 germination rate compared to the control. Pure mineral application resulted in reduced

355 plant growth, however, the phytotoxicity was reduced when the minerals were

356 incorporated into biochar due to buffered release of minerals (lower EC). A

357 combination of $\mathrm{pH}, \mathrm{EC} /$ potassium, $\mathrm{N}$-containing compounds and organic contaminants

358 (not measured) was responsible for the observed inhibitions. When BMCs are applied to

359 soil of low-buffering capacity, soil $\mathrm{pH}$ and EC have to be monitored closely to avoid

360 toxicity. BMCs derived from hydrothermal carbonization need to be post-treated to

361 reduce their concentrations of toxic organics. Taking these recommendations into

362 account, BMCs produced from mineral wastes (e.g., combustion ashes) and waste

363 biomass can be applied safely and can be great sources of nutrients and stable organic

364 carbon. 


\section{Acknowledgements}

366 The research conducted by the authors was supported by grants from a Marie Curie

367 Fellowship of Jan Mumme (grant no. 661323) and a travel grant from Max-Eyth

368 Foundation awarded to Josephine Getz. The authors would like to express their

369 gratitude to Laureen Herklotz for chemical analyses at ATB Potsdam and Clare Peters

370 for technical advice at the UK Biochar Research Centre. 
371

372

373

374

375

376

377

378

379

380

381

382

383

384

385

386

387

388

389

390

391

392

393

394

395

396

397

398

399

400

401

402

403

404

405

406

407

408

409

410

411

412

\section{References}

Antal, M.J., Grønli, M., 2003. The art, science, and technology of charcoal production. Ind. Eng. Chem. Res. 42, 1619-1640. https://doi.org/10.1021/ie0207919

Bargmann, I., Rillig, M.C., Buss, W., Kruse, A., Kuecke, M., 2013. Hydrochar and biochar effects on germination of spring barley. J. Agron. Crop Sci. 199, 360-373. https://doi.org/10.1111/jac.12024

Blackwell, P., Joseph, S., Munroe, P., Anawar, H.M., Storer, P., Gilkes, R.J., Solaiman, Z.M., 2015. Influences of Biochar and Biochar-Mineral Complex on Mycorrhizal Colonisation and Nutrition of Wheat and Sorghum. Pedosphere 25, 686-695. https://doi.org/10.1016/S1002-0160(15)30049-7

Busch, D., Stark, A., Kammann, C.I., Glaser, B., 2013. Genotoxic and phytotoxic risk assessment of fresh and treated hydrochar from hydrothermal carbonization compared to biochar from pyrolysis. Ecotoxicol. Environ. Saf. 97, 59-66. https://doi.org/10.1016/j.ecoenv.2013.07.003

Buss, W., Graham, M.C., Shepherd, G.J., Mašek, O., 2016a. Suitability of marginal biomass-derived biochars for soil amendment. Sci. Total Environ. 547, 314-322. https://doi.org/doi:10.1016/j.scitotenv.2015.11.148

Buss, W., Graham, M.C., Shepherd, J.G., Mašek, O., 2016b. Risks and benefits of marginal biomass-derived biochars for plant growth. Sci. Total Environ. 569-570, 496-506. https://doi.org/10.1016/j.scitotenv.2016.06.129

Buss, W., Mašek, O., 2014. Mobile organic compounds in biochar - a potential source of contamination - phytotoxic effects on cress seed (Lepidium sativum) germination. J. Environ. Manage. 137, 111-119. https://doi.org/10.1016/j.jenvman.2014.01.045

Buss, W., Mašek, O., Graham, M., Wüst, D., 2015. Inherent organic compounds in biochar-Their content, composition and potential toxic effects. J. Environ. Manage. 156, 150-157. https://doi.org/10.1016/j.jenvman.2015.03.035

Cantrell, K.B., Hunt, P.G., Uchimiya, M., Novak, J.M., Ro, K.S., 2012. Impact of pyrolysis temperature and manure source on physicochemical characteristics of biochar. Bioresour. Technol. 107, 419-428. https://doi.org/10.1016/j.biortech.2011.11.084

Chao, H.P., Peng, C.L., Lee, C.K., Han, Y.L., 2012. A study on sorption of organic compounds with different water solubilities on octadecyltrichlorosilane-modified NaY zeolite. J. Taiwan Inst. Chem. Eng. 43, 195-200. https://doi.org/10.1016/j.jtice.2011.10.002

Chia, C.H., Singh, B.P., Joseph, S., Graber, E.R., Munroe, P., 2014. Characterization of an enriched biochar. J. Anal. Appl. Pyrolysis 108, 26-34. https://doi.org/10.1016/j.jaap.2014.05.021

Donovan, S.M., Bateson, T., Gronow, J.R., Voulvoulis, N., 2010. Characterization of Compost-like Outputs from mechanical biological treatment of municipal solid waste. J. Air Waste Manage. Assoc. 60, 694-701. https://doi.org/10.3155/10473289.60.6.694 
413

414

415

416

417

418

419

420

421

422

423

424

425

426

427

428

429

430

431

432

433

434

435

436

437

438

439

440

441

442

443

444

445

446

447

448

449

450

451

452

453

Enders, A., Lehmann, J., 2012. Comparison of wet-digestion and dry-ashing methods for total elemental analysis of biochar. Commun. Soil Sci. Plant Anal. 43, 10421052. https://doi.org/10.1080/00103624.2012.656167

Etiegni, L., Mahler, R.L., Campbell, A.G., Shafii, B., 1991. Evaluation of wood ash disposal on agricultural land. II. Potential toxic effects on plant growth. Commun. Soil Sci. Plant Anal. 22, 257-267. https://doi.org/10.1080/00103629109368413

Gell, K., van Groenigen, J., Cayuela, M.L., 2011. Residues of bioenergy production chains as soil amendments: immediate and temporal phytotoxicity. J. Hazard. Mater. 186, 2017-2025. https://doi.org/10.1016/j.jhazmat.2010.12.105

Henig-Sever, N., Eshel, A., Ne'eman, G., 1996. pH and osmotic potential of pine ash as post-fire germination inhibitors. Physiol. Plant. 96, 71-76. https://doi.org/10.1034/j.1399-3054.1996.960111.x

IBI, 2014. International Biochar Initiative - Standardized product definition and product testing guidelines for biochar that is used in soil - version 2.0. https://doi.org/http://www.biochar-international.org/characterizationstandard. 22

International Biochar Initiative, 2011. Standardized product definition and product testing guidelines for biochar that is used in soil, v. 1.1, April 11th 2013.

Jaworski, C., Valli, V., 1964. Tomato seed germination and plant growth in relation to soil temperatures and phosphorous levels. Proc. Fla. State Hort. Sci 177-183.

Jindo, K., Mizumoto, H., Sawada, Y., Sonoki, T., 2014. Physical and chemical characterization of biochars derived from different agricultural residues. Biogeosciences 11, 6613-6621. https://doi.org/10.5194/bg-11-6613-2014

Kołtowski, M., Oleszczuk, P., 2015. Toxicity of biochars after polycyclic aromatic hydrocarbons removal by thermal treatment. Ecol. Eng. 75, 79-85. https://doi.org/10.1016/j.ecoleng.2014.11.004

Lehmann, J., Joseph, S., 2015. Chapter 1: Biochar for environmental managment: an introduction, in: Biochar for Environmental Management: Science and Technology and Implementation, Second Edition. Earthscan Ltd., London., pp. 1-13.

Li, F., Cao, X., Zhao, L., Wang, J., Ding, Z., 2014. Effects of mineral additives on biochar formation: Carbon retention, stability, and properties. Environ. Sci. Technol. 48, 11211-11217. https://doi.org/10.1021/es501885n

Libra, J.A., Ro, K.S., Kammann, C., Funke, A., Berge, N.D., Neubauer, Y., Titirici, M.M., Fühner, C., Bens, O., Kern, J., Emmerich, K.-H., 2011. Hydrothermal carbonization of biomass residuals: a comparative review of the chemistry, processes and applications of wet and dry pyrolysis. Biofuels 2, 71-106. https://doi.org/10.4155/bfs.10.81

Lin, Y., Munroe, P., Joseph, S., Ziolkowski, A., van Zwieten, L., Kimber, S., Rust, J., 2013. Chemical and structural analysis of enhanced biochars: Thermally treated mixtures of biochar, chicken litter, clay and minerals. Chemosphere 91, 35-40. https://doi.org/10.1016/j.chemosphere.2012.11.063

Liu, X., Zhang, A., Ji, C., Joseph, S., Bian, R., Lianqing, L., Pan, G., Paz-Ferreiro, J., 
454

455

456

457

458

459

460

461

462

463

464

465

466

467

468

469

470

471

472

473

474

475

476

477

478

479

480

481

482

483

484

485

486

487

488

489

490

491

492

493

494

2013. Biochar's effect on crop productivity and the dependence on experimental conditions - a meta-analysis of literature data. Plant Soil 373, 583-594.

Lucchini, P., Quilliam, R.S., DeLuca, T.H., Vamerali, T., Jones, D.L., 2014. Increased bioavailability of metals in two contrasting agricultural soils treated with waste wood-derived biochar and ash. Environ. Sci. Pollut. Res. 21, 3230-3240. https://doi.org/10.1007/s11356-013-2272-y

Monaco, T.A., Mackown, C., Johnson, D., Jones, T., Norton, J., Norton, J., Redinbaugh, M., 2003. Nitrogen effects on seed germination and seedling growth. J Range Manag. 56, 646-653.

Mumme, J., Srocke, F., Heeg, K., Werner, M., 2014. Use of biochars in anaerobic digestion. Bioresour. Technol. 164, 189-197. https://doi.org/10.1016/j.biortech.2014.05.008

Mumme, J., Titirici, M.M., Pfeiffer, A., Lüder, U., Reza, M.T., Mašek, O., 2015. Hydrothermal Carbonization of Digestate in the Presence of Zeolite: Process Efficiency and Composite Properties. ACS Sustain. Chem. Eng. 3, 2967-2974. https://doi.org/10.1021/acssuschemeng.5b00943

Oleszczuk, P., Jośko, I., Kuśmierz, M., 2013. Biochar properties regarding to contaminants content and ecotoxicological assessment. J. Hazard. Mater. 260, 375-382. https://doi.org/10.1016/j.jhazmat.2013.05.044

Penny, M.G., Moore, K.G., Lovell, P.H., 1976. Some effects of potassium deficiency on seedling development. Ann. Bot. 801-814.

Prommer, J., Wanek, W., Hofhansl, F., Trojan, D., Offre, P., Urich, T., Schleper, C., Sassmann, S., Kitzler, B., Soja, G., Hood-Nowotny, R.C., 2014. Biochar decelerates soil organic nitrogen cycling but stimulates soil nitrification in a temperate arable field trial. PLoS One 9.

https://doi.org/10.1371/journal.pone.0086388

Rajkovich, S., Enders, A., Hanley, K., Hyland, C., Zimmerman, A.R., Lehmann, J., 2012. Corn growth and nitrogen nutrition after additions of biochars with varying properties to a temperate soil. Biol. Fertil. Soils 48, 271-284. https://doi.org/10.1007/s00374-011-0624-7

Ramírez, W.A., Domene, X., Ortiz, O., Alcañiz, J.M., 2008. Toxic effects of digested, composted and thermally-dried sewage sludge on three plants. Bioresour. Technol. 99, 7168-7175. https://doi.org/10.1016/j.biortech.2007.12.072

Ronsse, F., van Hecke, S., Dickinson, D., Prins, W., 2013. Production and characterization of slow pyrolysis biochar: influence of feedstock type and pyrolysis conditions. GCB Bioenergy 5, 104-115. https://doi.org/10.1111/gcbb.12018

Singh, V.P., Mall, S.L., Billore, S.K., 1975. Effect of pH on germination of four common grass species of Ujjain (India). J. Range Manag. 28, 497-498.

Smith, C.R., Buzan, E.M., Lee, J.W., 2013. Potential impact of biochar waterextractable substances on environmental sustainability. ACS Sustain. Chem. Eng. 
Wang, J., Xiong, Z., Kuzyakov, Y., 2015. Biochar stability in soil: Meta-analysis of decomposition and priming effects. GCB Bioenergy 1-12. https://doi.org/10.1111/gcbb.12266

Wong, M.H., 1985. Phytotoxicity of refuse compost during the process of maturation. Environ. Pollution. Ser. A, Ecol. Biol. 37, 159-174. https://doi.org/10.1016/01431471(85)90006-6

Xie, T., Reddy, K.R., Wang, C., Yargicoglu, E., 2015. Characteristics and applications of biochar for environmental remediation: A review. Crit. Rev. Environ. Sci. Technol. 45, 939-969. https://doi.org/10.1080/10643389.2014.924180

Xu, X., Zhao, Y., Sima, J., Zhao, L., Mašek, O., Cao, X., 2017. Indispensable role of biochar-inherent mineral constituents in its environmental applications: A review. Bioresour. Technol. 241, 887-899. https://doi.org/10.1016/j.biortech.2017.06.023

Yao, F.X., Arbestain, M.C., Virgel, S., Blanco, F., Arostegui, J., Maciá-Agulló, J. a, Macías, F., 2010. Simulated geochemical weathering of a mineral ash-rich biochar in a modified Soxhlet reactor. Chemosphere 80, 724-32. https://doi.org/10.1016/j.chemosphere.2010.05.026

Zhu, L., Yin, S., Yin, Q., Wang, H., Wang, S., 2015. Biochar: A new promising catalyst support using methanation as a probe reaction. Energy Sci. Eng. 3, 126-134. https://doi.org/10.1002/ese3.58 
516 Table 1 Bulk properties of feedstocks, pure biochars and BMCs derived from

517 sewage sludge $(n=1)$.

\begin{tabular}{|c|c|c|c|c|c|c|c|c|c|}
\hline mineral type & mineral ratio & process & $\begin{array}{c}\mathrm{pH} \\
\left(\mathrm{H}_{2} \mathrm{O}\right)\end{array}$ & $\begin{array}{c}\mathrm{EC} \\
\mu \mathrm{S} \mathrm{cm}^{-1}\end{array}$ & $\begin{array}{c}\operatorname{Ash}_{550} \\
\% \text { dry }\end{array}$ & $\begin{array}{c}\mathrm{C} \\
\% \text { dry }\end{array}$ & $\begin{array}{c}\mathrm{N} \\
\% \text { dry }\end{array}$ & $\begin{array}{c}\mathrm{H} \\
\% \text { dry }\end{array}$ & $\begin{array}{c}\mathrm{S} \\
\% \text { dry }\end{array}$ \\
\hline \multicolumn{3}{|c|}{ Zeolite } & 6.79 & 19.9 & 100 & 0.004 & 0 & 1.32 & 0.037 \\
\hline \multicolumn{3}{|c|}{ Wood ash } & 12.78 & 16100 & 99.50 & 6.60 & 0 & 0.37 & 1.11 \\
\hline \multicolumn{3}{|c|}{ Fly ash } & 12.54 & 8170 & 99.78 & 0.42 & 0 & 0.19 & 3.00 \\
\hline \multicolumn{3}{|c|}{ Raw sewage sludge } & 6.76 & 388 & 29.65 & 39.74 & 4.28 & 6.20 & 0.66 \\
\hline \multirow{3}{*}{\multicolumn{2}{|c|}{ Without mineral }} & HTC190 & 4.40 & 149 & 39.36 & 38.33 & 2.08 & 5.25 & 0.57 \\
\hline & & HTC230 & 4.70 & 50.3 & 45.20 & 38.82 & 2.11 & 4.79 & 0.52 \\
\hline & & Pyro550 & 6.73 & 31.6 & 57.49 & 31.80 & 3.87 & 2.21 & 0.63 \\
\hline \multirow[t]{6}{*}{ Zeolite } & \multirow[t]{3}{*}{$1: 10$} & HTC190 & 5.54 & 134 & 52.38 & 32.77 & 2.21 & 4.43 & 0.72 \\
\hline & & HTC230 & 5.16 & 208 & 50.53 & 35.27 & 2.19 & 4.84 & 0.63 \\
\hline & & Pyro550 & 6.95 & 114 & 63.45 & 27.47 & 3.33 & 2.04 & 0.55 \\
\hline & \multirow[t]{3}{*}{$1: 1$} & HTC190 & 4.94 & 182 & 74.40 & 15.93 & 1.17 & 2.71 & 0.30 \\
\hline & & HTC230 & 5.27 & 125 & 83.33 & 12.08 & 1.26 & 2.36 & 0.29 \\
\hline & & Pyro550 & 7.75 & 45.3 & 84.10 & 11.57 & 1.54 & 1.53 & 0.26 \\
\hline \multirow[t]{6}{*}{ Wood ash } & \multirow[t]{3}{*}{$1: 10$} & HTC190 & 6.63 & 593 & 43.38 & 34.74 & 1.93 & 5.03 & 0.66 \\
\hline & & HTC230 & 6.46 & 208 & 50.11 & 33.87 & 1.80 & 4.56 & 0.71 \\
\hline & & Pyro550 & 9.71 & 470 & 62.25 & 27.48 & 2.97 & 2.17 & 0.93 \\
\hline & \multirow[t]{3}{*}{$1: 1$} & HTC190 & 10.66 & 1050 & 71.69 & 20.18 & 0.57 & 2.70 & 0.57 \\
\hline & & HTC230 & 9.32 & 232 & 83.46 & 14.56 & 0.27 & 1.87 & 0.56 \\
\hline & & Pyro550 & 11.31 & 4040 & 83.66 & 13.84 & 0.74 & 0.99 & 1.11 \\
\hline \multirow[t]{4}{*}{ Lignite fly ash } & \multirow[t]{4}{*}{$1: 10$} & HTC190 & 5.81 & 334 & 44.77 & 33.96 & 1.95 & 5.10 & 0.82 \\
\hline & & HTC230 & 5.43 & 388 & 51.99 & 34.36 & 1.91 & 4.71 & 0.92 \\
\hline & & HTC190 & 9.12 & 354 & 71.07 & 17.55 & 0.68 & 2.71 & 1.79 \\
\hline & & HTC230 & 7.88 & 244 & 71.61 & 19.58 & 0.62 & 2.74 & 1.56 \\
\hline
\end{tabular}


519 Table 2 Bulk properties of feedstock, pure biochars and BMCs derived from CLO

$520 \quad(\mathrm{n}=1)$.

\begin{tabular}{|c|c|c|c|c|c|c|c|c|c|c|}
\hline mineral type & \multirow{2}{*}{$\begin{array}{c}\begin{array}{c}\text { mineral } \\
\text { ratio }\end{array} \\
\text { Raw CLO }\end{array}$} & \multirow[t]{2}{*}{ process } & \multicolumn{2}{|c|}{$\begin{array}{c}\mathrm{pH} \\
\left(\mathrm{H}_{2} \mathrm{O}\right)\end{array}$} & $\begin{array}{l}\mathrm{EC} \\
\mathrm{S} \mathrm{cm}^{-1}\end{array}$ & $\begin{array}{l}\text { Ash }_{550} \\
\% \text { dry }\end{array}$ & $\begin{array}{c}\mathrm{C} \\
\% \mathrm{dry}\end{array}$ & $\begin{array}{c}\mathrm{N} \\
\% \text { dry }\end{array}$ & $\begin{array}{c}\mathrm{H} \\
\% \text { dry }\end{array}$ & $\begin{array}{c}\mathrm{S} \\
\% \text { dry }\end{array}$ \\
\hline & & & 8.31 & 1980 & 55.03 & 24.03 & 2.49 & 3.14 & & .45 \\
\hline Without & & HTC190 & 7.00 & 758 & 66.62 & 23.75 & 1.20 & 2.17 & & .80 \\
\hline \multirow[t]{2}{*}{ mineral } & & HTC230 & 7.21 & 745 & 67.72 & 26.30 & 1.29 & 2.24 & & .94 \\
\hline & & Pyro550 & 8.95 & 1420 & 69.77 & 21.43 & 1.50 & 1.58 & & .16 \\
\hline \multirow[t]{6}{*}{ Zeolite } & $1: 10$ & HTC190 & 6.83 & 781 & 59.07 & 26.85 & 1.52 & 3.07 & & .92 \\
\hline & & HTC230 & 7.20 & 706 & 68.55 & 23.63 & 1.23 & 2.35 & & .90 \\
\hline & & Pyro550 & 8.28 & 834 & 70.56 & 21.50 & 1.46 & 1.63 & & .16 \\
\hline & $1: 1$ & HTC190 & 6.58 & 491 & 81.71 & 12.98 & 0.77 & 1.99 & & .44 \\
\hline & & HTC230 & 6.95 & 473 & 85.28 & 10.98 & 0.75 & 1.80 & & .38 \\
\hline & & Pyro550 & 8.57 & 711 & 84.83 & 10.45 & 0.77 & 1.48 & & .53 \\
\hline \multirow[t]{6}{*}{ Wood ash } & 1:10 & HTC190 & 7.69 & 791 & 63.98 & 25.30 & 1.22 & 2.48 & & .94 \\
\hline & & HTC230 & 7.56 & 794 & 65.36 & 25.31 & 1.19 & 2.39 & & .10 \\
\hline & & Pyro550 & 9.74 & 2280 & 72.43 & 20.36 & 1.13 & 1.18 & & .34 \\
\hline & $1: 1$ & HTC190 & 10.96 & 1290 & 84.32 & 13.36 & 0.25 & 1.29 & & .42 \\
\hline & & HTC230 & 11.16 & 1320 & 87.41 & 12.26 & 0.18 & 1.09 & & .46 \\
\hline & & Pyro550 & 11.76 & 5710 & 87.63 & 11.79 & 0.37 & 0.67 & & .16 \\
\hline \multirow{4}{*}{$\begin{array}{l}\text { Lignite fly } \\
\text { ash }\end{array}$} & $1: 10$ & HTC190 & 6.98 & 991 & 65.83 & 23.61 & 1.25 & 2.49 & & .26 \\
\hline & & HTC230 & 7.53 & 784 & 65.83 & 24.33 & 1.16 & 2.42 & & .34 \\
\hline & $1: 1$ & HTC190 & 10.02 & 684 & 81.43 & 11.82 & 0.41 & 1.76 & & .31 \\
\hline & & HTC 230 & 9.97 & 574 & 83.84 & 10.35 & 0.30 & 1.28 & & .06 \\
\hline
\end{tabular}


521 Table 3 Plant nutrient concentrations $\left(\mathrm{mg} \mathrm{kg}^{-1}\right)$ in the feedstocks and their resulting hydrochars produced at 190 and $230^{\circ} \mathrm{C}$ and pyrolysis chars 522 produced at $550^{\circ} \mathrm{C}$ from pure and mixed materials derived from sewage sludge $(n=1)$.

\begin{tabular}{|c|c|c|c|c|c|c|c|c|c|}
\hline mineral type & mineral ratio & process & $\begin{array}{c}\mathrm{P} \\
\mathrm{mg} \mathrm{kg}^{-1}\end{array}$ & $\begin{array}{c}\mathrm{K} \\
\mathrm{mg} \mathrm{kg}^{-1}\end{array}$ & $\begin{array}{c}\mathrm{Ca} \\
\mathrm{mg} \mathrm{kg}^{-1}\end{array}$ & $\begin{array}{c}\mathrm{Mg} \\
\mathrm{mg} \mathrm{kg}^{-1}\end{array}$ & $\begin{array}{c}\mathrm{Mn} \\
\mathrm{mg} \mathrm{kg}^{-1}\end{array}$ & $\begin{array}{c}\mathrm{S} \\
\mathrm{mg} \mathrm{kg}^{-1}\end{array}$ & $\begin{array}{c}\text { B } \\
\mathrm{mg} \mathrm{kg}^{-1}\end{array}$ \\
\hline & Zeolite & & 58.5 & 14051 & 7346 & 348 & 20.8 & 113 & 2.66 \\
\hline & Fly ash & & 178 & 1221 & 194884 & 11855 & 795 & 27199 & 162 \\
\hline & Wood ash & & 7697 & 75652 & 272484 & 19250 & 4322 & 9246 & 243 \\
\hline \multicolumn{3}{|c|}{ Raw sewage sludge } & 11152 & 1520 & 9342 & 3185 & 386 & 4120 & 19 \\
\hline \multirow{4}{*}{$\begin{array}{l}\text { Without } \\
\text { mineral }\end{array}$} & & HTC190 & 16262 & 1083 & 11704 & 4065 & 516 & 3496 & 38.2 \\
\hline & & HTC230 & 18732 & 1570 & 14514 & 5100 & 626 & 3763 & 24.1 \\
\hline & & Pyro550 & 24282 & 2970 & 17909 & 6602 & 792 & 4923 & 9.47 \\
\hline & $1: 10$ & HTC190 & 16782 & 2970 & 15029 & 4630 & 528 & 4140 & 3.28 \\
\hline \multirow{5}{*}{ Zeolite } & & HTC230 & 17012 & 3207 & 15219 & 4759 & 535 & 3825 & 3.26 \\
\hline & & Pyro550 & 19712 & 5516 & 16804 & 5420 & 615 & 4154 & 9.16 \\
\hline & $1: 1$ & HTC190 & 5298 & 8483 & 7417 & 1260 & 134 & 1159 & 33.5 \\
\hline & & HTC230 & 8149 & 7752 & 11459 & 2087 & 201 & 2076 & 52.3 \\
\hline & & Pyro550 & 6897 & 11861 & 11939 & 2276 & 188 & 1529 & 60.4 \\
\hline \multirow{6}{*}{ Wood ash } & $1: 10$ & HTC190 & 15212 & 3262 & 30839 & 5287 & 841 & 4223 & 8.39 \\
\hline & & HTC230 & 17292 & 3374 & 40499 & 6663 & 1036 & 5544 & 11.3 \\
\hline & & Pyro550 & 20382 & 14892 & 57679 & 8181 & 1303 & 7854 & 35.2 \\
\hline & $1: 1$ & HTC190 & 11072 & 12446 & 174434 & 14055 & 3096 & 4353 & 177 \\
\hline & & HTC230 & 7451 & 10121 & 165534 & 12355 & 2740 & 4748 & 114 \\
\hline & & Pyro550 & 10042 & 51129 & 181484 & 14165 & 3180 & 9859 & 186 \\
\hline Lignite fly & $1: 10$ & HTC190 & 15332 & 1640 & 25464 & 4653 & 541 & 5038 & 4.66 \\
\hline
\end{tabular}




$\begin{array}{cccccccc}\text { HTC230 } & 17082 & 1794 & 32039 & 5826 & 628 & 6622 & 5.14 \\ \text { HTC190 } & 736 & 996 & 127584 & 9095 & 716 & 24979 & 96.7 \\ \text { HTC230 } & 3564 & 923 & 113534 & 8462 & 702 & 20976 & 63.5\end{array}$


524 Table 4 Plant nutrient concentrations $\left(\mathrm{mg} \mathrm{kg}^{-1}\right)$ in the feedstock and their resulting hydrochars produced at 190 and $230^{\circ} \mathrm{C}$ and pyrolysis chars

525 produced at $550^{\circ} \mathrm{C}$ from pure and mixed materials derived from CLO $(\mathrm{n}=1)$.

\begin{tabular}{|c|c|c|c|c|c|c|c|c|c|}
\hline mineral type & mineral ratio & process & $\begin{array}{c}\mathrm{P} \\
\mathrm{mg} \mathrm{kg}^{-1}\end{array}$ & $\begin{array}{c}\mathrm{K} \\
\mathrm{mg} \mathrm{kg}^{-1}\end{array}$ & $\begin{array}{c}\mathrm{Ca} \\
\mathrm{mg} \mathrm{kg}^{-1}\end{array}$ & $\begin{array}{c}\mathrm{Mg} \\
\mathrm{mg} \mathrm{kg}^{-1}\end{array}$ & $\begin{array}{c}\mathrm{Mn} \\
\mathrm{mg} \mathrm{kg}^{-1}\end{array}$ & $\begin{array}{c}\mathrm{S} \\
\mathrm{mg} \mathrm{kg}^{-1}\end{array}$ & $\begin{array}{c}\text { B } \\
\mathrm{mg} \mathrm{kg}^{-1}\end{array}$ \\
\hline \multirow{4}{*}{$\begin{array}{l}\text { Without } \\
\text { mineral }\end{array}$} & \multirow[t]{4}{*}{ Raw CLO } & & 4250 & 7788 & 64309 & 5255 & 484 & 10446 & 33.85 \\
\hline & & HTC190 & 4297 & 1735 & 65609 & 5335 & 523 & 7498 & 9.31 \\
\hline & & HTC230 & 4786 & 1737 & 65874 & 5063 & 506 & 7887 & 11.2 \\
\hline & & Pyro550 & 5376 & 9697 & 79224 & 6230 & 584 & 12356 & 35.7 \\
\hline \multirow{6}{*}{ Zeolite } & \multirow[t]{3}{*}{ 1:10 } & HTC190 & 4129 & 5048 & 59584 & 5070 & 466 & 7003 & 8.22 \\
\hline & & HTC230 & 5006 & 6662 & 65499 & 5862 & 557 & 9369 & 9.76 \\
\hline & & Pyro550 & 4648 & 10394 & 69729 & 5324 & 485 & 10098 & 56.5 \\
\hline & \multirow[t]{3}{*}{$1: 1$} & HTC190 & 1689 & 9323 & 33309 & 2076 & 184 & 3107 & 4.01 \\
\hline & & HTC230 & 1993 & 9198 & 36774 & 2793 & 198 & 3113 & 5.81 \\
\hline & & Pyro550 & 1644 & 14739 & 36169 & 2419 & 200 & 4338 & 16.3 \\
\hline \multirow{6}{*}{ Wood ash } & \multirow[t]{3}{*}{$1: 10$} & HTC190 & 5093 & 3830 & 100764 & 6593 & 932 & 7930 & 22.7 \\
\hline & & HTC230 & 5194 & 4129 & 93484 & 7408 & 888 & 7097 & 27.2 \\
\hline & & Pyro550 & 5938 & 19276 & 115184 & 8885 & 1106 & 12794 & 84.9 \\
\hline & \multirow[t]{3}{*}{$1: 1$} & HTC190 & 4073 & 11726 & 169984 & 11745 & 2166 & 3149 & 151 \\
\hline & & HTC230 & 5273 & 12336 & 171484 & 12735 & 2360 & 3813 & 154 \\
\hline & & Pyro550 & 6364 & 53659 & 210284 & 14535 & 3176 & 10776 & 171 \\
\hline \multirow{4}{*}{$\begin{array}{l}\text { Lignite fly } \\
\text { ash }\end{array}$} & \multirow[t]{2}{*}{$1: 10$} & HTC190 & 4861 & 2037 & 85534 & 6534 & 630 & 13299 & 19.7 \\
\hline & & HTC230 & 4500 & 2079 & 88599 & 6428 & 580 & 11721 & 17.6 \\
\hline & \multirow[t]{2}{*}{$1: 1$} & HTC190 & 2029 & 1375 & 110584 & 7217 & 763 & 18666 & 75.6 \\
\hline & & HTC230 & 2055 & 1488 & 119434 & 8181 & 692 & 19656 & 80.8 \\
\hline
\end{tabular}



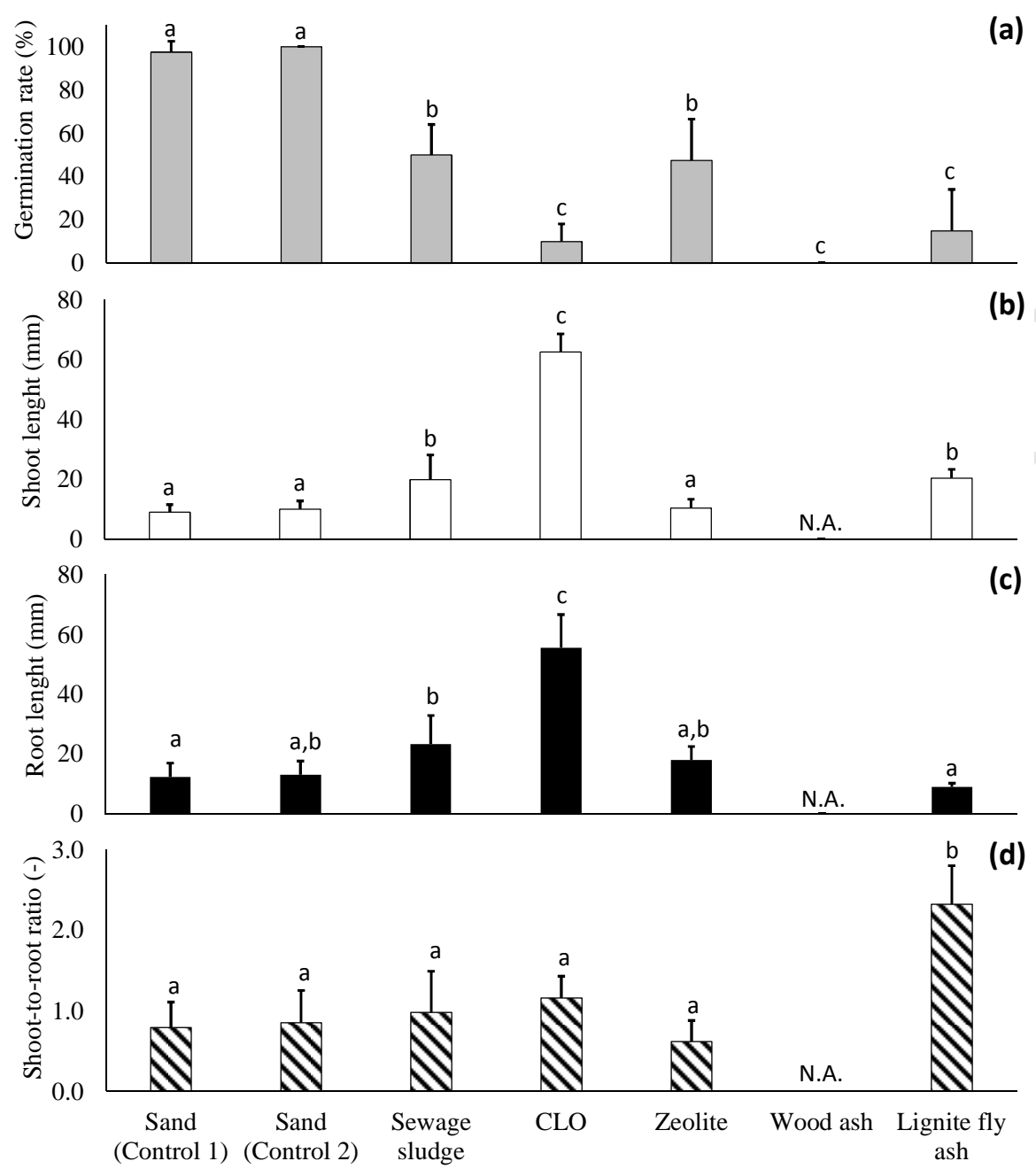

527 Fig. 1 Cress vitality parameters of Controls, raw feedstocks and pure minerals. Means

528 and standard deviations of four replicates. Different letters indicate statistically

529 significant differences $(\mathrm{P}<0.05)$. 

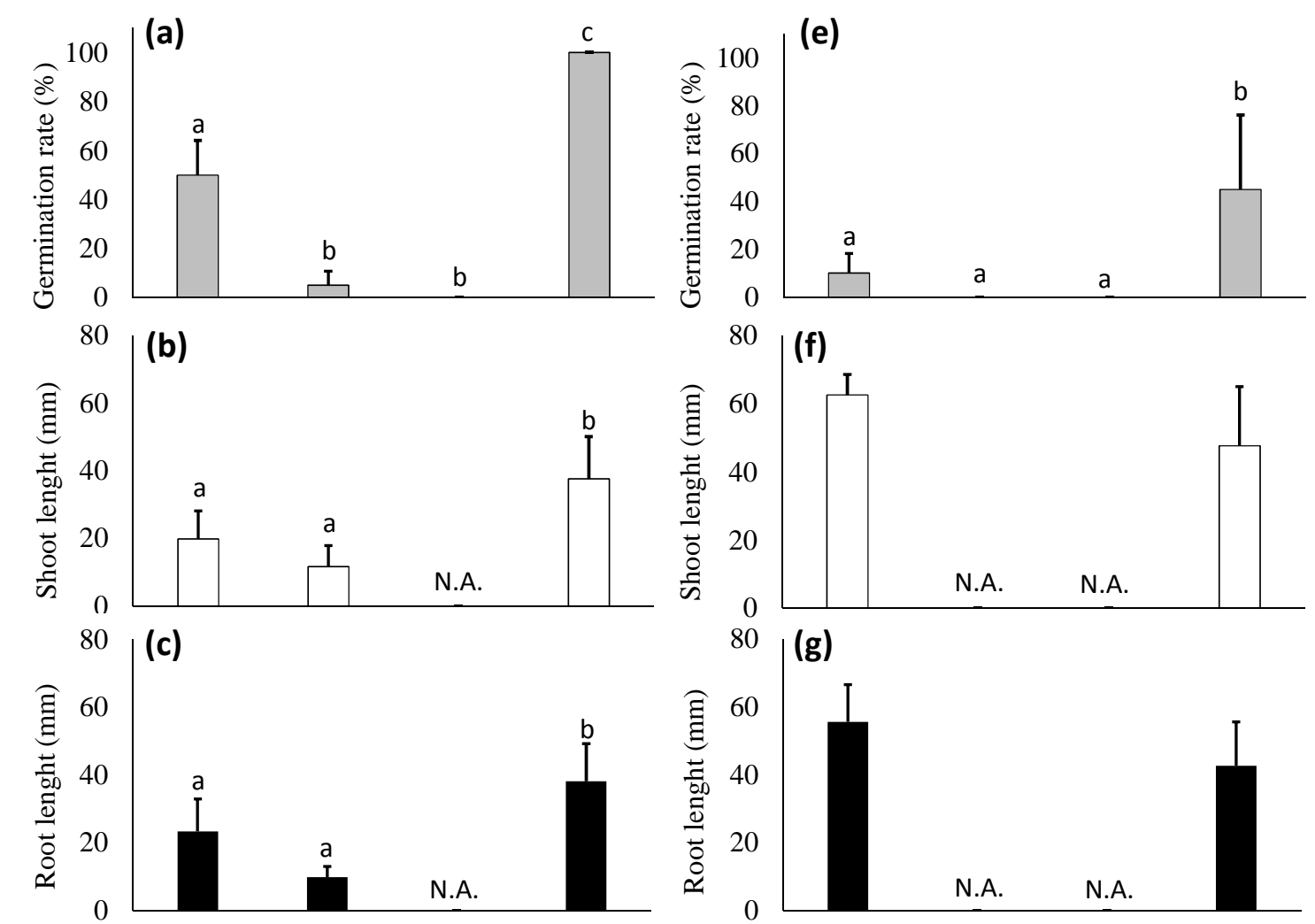

80

(f)


531 Fig. 2 Impact of HTC and pyrolysis treatment of sewage sludge (a-d) and CLO (e-h) on

532 cress vitality parameters (without mineral addition). Means and standard deviations of

533 four replicates. Different letters indicate statistically significant differences $(\mathrm{P}<0.05)$.

534 N.A. $=$ not applicable. 

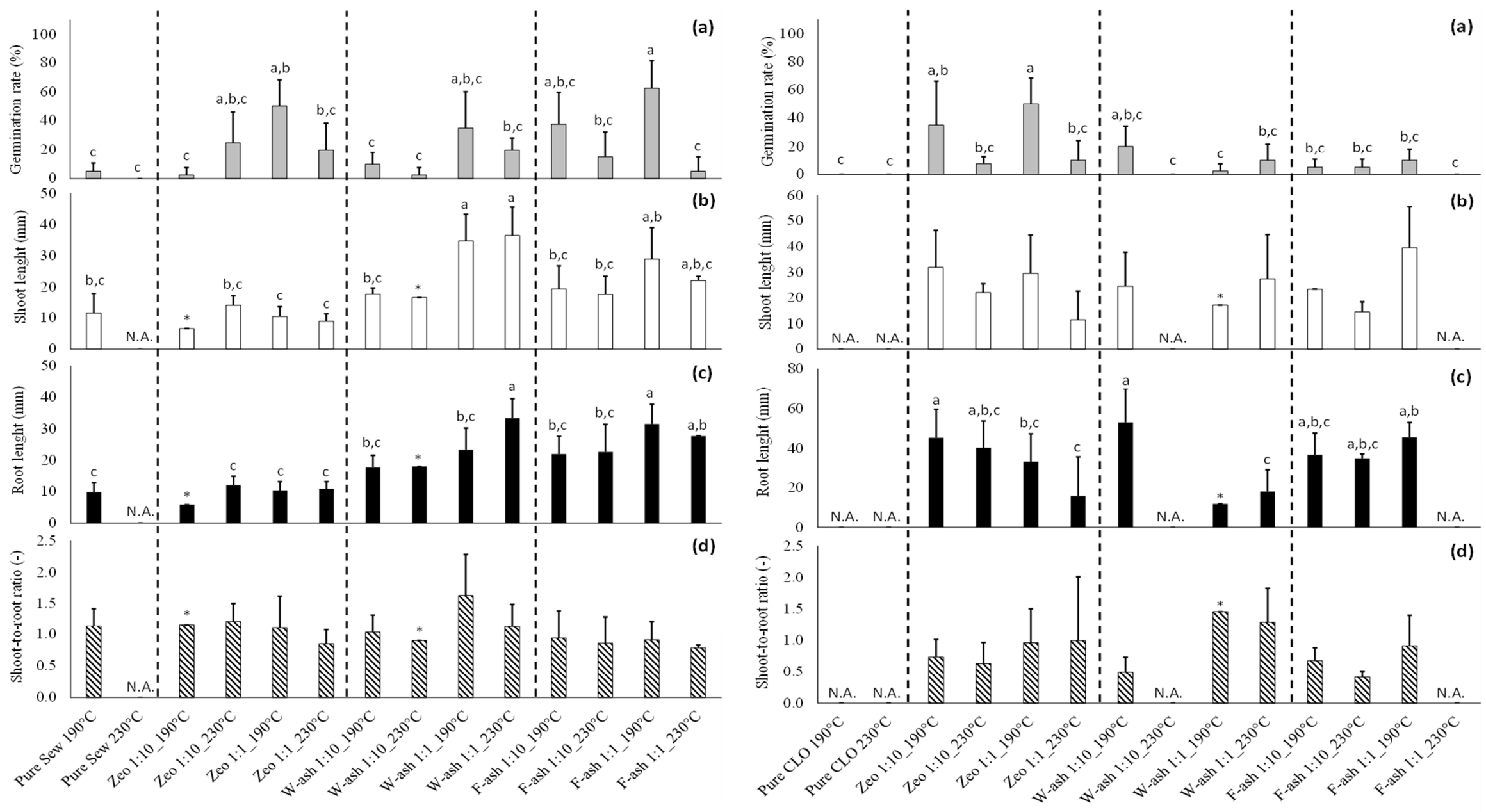
536 Fig. 3 Impact of HTC-derived BMCs from sewage sludge (Sew) and CLO with zeolite (Zeo), wood ash (W-ash) and lignite fly ash (F-ash)

537 on cress vitality parameters. Means and standard deviations of four replicates. Different letters indicate statistically significant differences

$538(\mathrm{P}<0.05)$ and asterisk indicate single measurement values. N.A. = not applicable. 

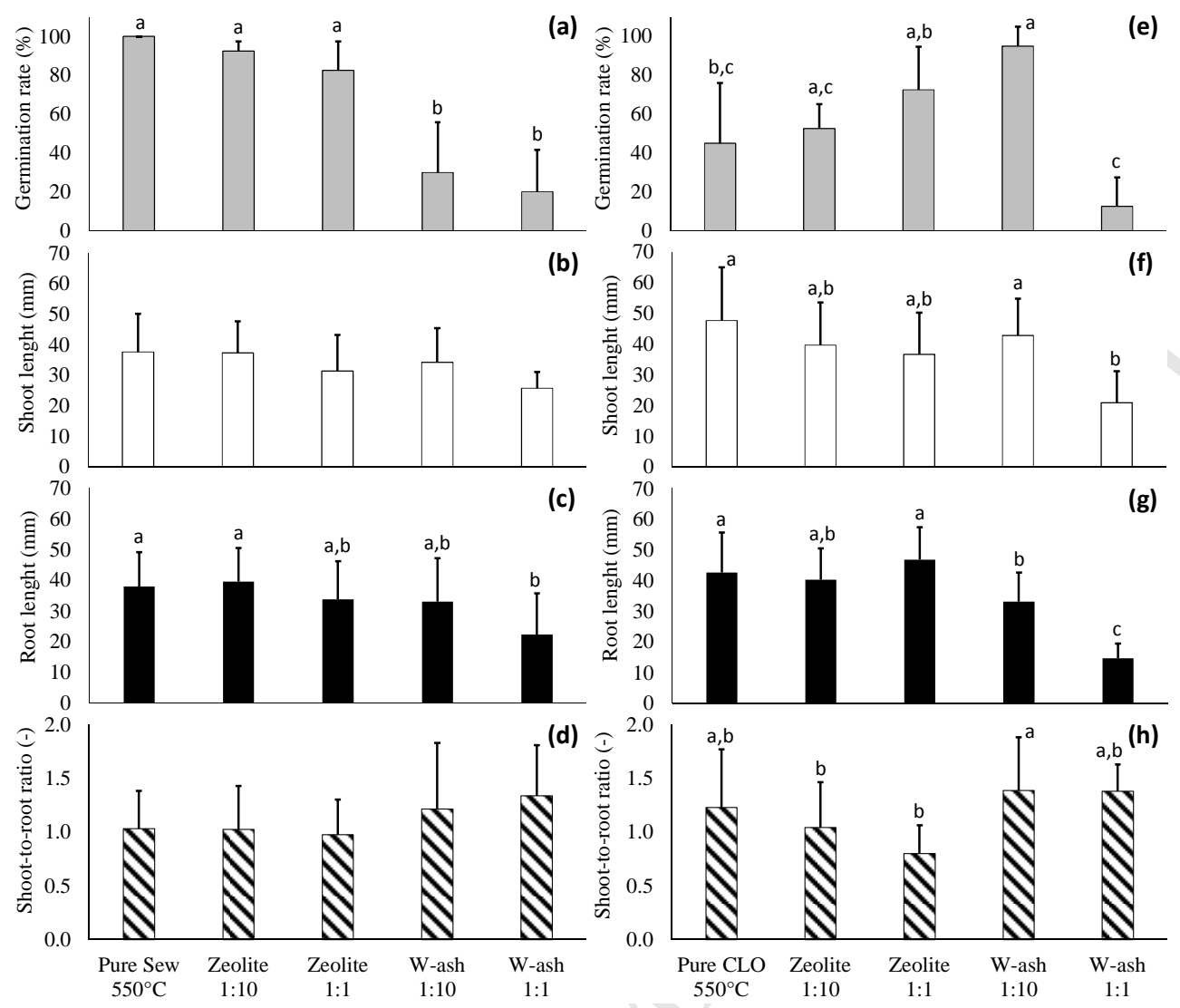

540 Fig. 4 Impact of pyrolysis-derived BMCs from sewage sludge (Sew) (a-d) and CLO (e-

541 h) on cress vitality parameters. Means and standard deviations of four replicates.

542 Different letters indicate statistically significant differences $(\mathrm{P}<0.05)$. N.A. $=$ not

543 applicable. 


\section{Highlights}

- Effects of biochar-mineral composites on water cress germination were studied

- Addition of minerals can reduce the toxicity of HTC products

- Wood ash addition to pyrolysed compost can improve cress germination rate

- Wood ash addition to pyrolysed sewage sludge reduced cress germination rate

- Many pyrolysis-derived BMCs increased plant growth 